\title{
Modeling and analyzing the impact of lean principles on organizational performance using ISM approach
}

\author{
Rajender Kumara*, Vikas Kumar $^{\text {b }}$ and Sultan Singh $^{\mathrm{c}}$
}

${ }^{a}$ Research Scholar, MED, YMCAUST and Asst. Prof., MED, FET, MRIU, Faridabad, India

${ }^{b}$ Professor, MED, YMCAUST, Faridabad, India

'Joint Director, Technical Education Haryana, Panchkula, India

\section{CHRON I C L E A B S T RACT}

Article history:

Received: January 15, 2017

Received in revised format: February 16,2017

Accepted: May 11, 2017

Available online:

May 12, 2017

Keywords:

Lean Principles

Wastages

ISM approach

Performance

\begin{abstract}
Existing literature on lean principles reveals the impact of lean principles on the organizational performance. During the past few years, the Indian manufacturing context has been competing with the global competitors directly to sustain their presence. One of the big motivations behind this is the steps taken in favor of replacing the policies and regulations for the manufacturing context by the government of India. In present, the manufacturing context is still far away to get the sustainable market because of customer perception variation i.e. cost, delivery and quality related issues. To overcome the uncertainties based on the attributes i.e. quality, productivity, delivery etc., almost all the manufacturing units use the basic of lean principle i.e. apply the 5'S. Whereas the heavy industries used the VSM approach especially the automotive product manufacturers. The work presented in this paper gives an insight on the application of lean principles in the manufacturing context and analyzes the impacts using ISM approach.
\end{abstract}

2017 Growing Science Ltd.

\section{Introduction}

In present, the scenario of the global market is full of crisis because of customer perception variation. As the customer perception varies, the organizations have to reinvent their existing process through the innovations (Kumar et al., 2014). In addition, the organizations transform the business thinking, to flow with the stream of changing trends. To do so, almost all the organizations are intended to focus on to the customer, which further leads to build the sustainable competitive advantage (Bhasin \& Burcher, 2006; Abdulmalek \& Rajgopal, 2007; Sahoo et al., 2008). The concept of focus on customer is not the new one. In 1887, William Cooper Procter, grandson of the founder of Procter \& Gamble, addressed the workforce to adopt the quality merchandise as the first job, so the customer keeps on buying. He addressed three major issues at that time i.e. productivity, cost and quality (Evans \& Lindsay, 2004). In the beginning of $19^{\text {th }}$ century, the customer perception was the main driving force to run any business reported by Dr. J.M. Juran (quality guru), by giving the definition to the quality as the "fitness for purpose" (Buffa \& Sarin, 2011).

* Corresponding author.

E-mail address: rajender.fet@mriu.edu.in (R. Kumar) 
The Second World War was closed with the domination on economic scale of the countries such as Japan, Germany and Italy. At that time, it seemed that they would never recover with this domination in coming 100 years. Later on, coming to the 1980's, Japan became the leader to produce the good quality products in worldwide. By implying the advanced technologies such as TPM, LM, JIT, QM, TQM, Taguchi, 5-S etc. to improve the quality and productivity, Japan was become the global leader (Hines, 2008; Upadhye et al., 2010).

At the same time, the Indian manufacturing context was not aware with these tools to improve the manufacturing GDP and they were working on the traditional approach. Due to this fact, the Indian manufacturing context faced the challenges in the global market. Now, from the past one decade, India becomes the prominent place, which provides contingent solution for the global manufacturers. That'swhy, the technological advancement is much needed aspect for the Indian manufacturing context to sustain in the global market (Kumar et al., 2015a; Threja \& Sharma, 2011; Belokar et al., 2012)

The emergence of Lean Principles or Lean Manufacturing approach was reported in a book titled "The Machine That Changed the World" (Womack et al. 1990). The Lean Principles have the similarities of Toyota production System. So, the use of this approach was widely accepted by the firms who were already employed the TPS (Liker, 2004). Lean Principles were developed for imparting the flexibility in the mass production by eliminating the wastages (Sohal, 1996; Guliyani, 2001; Shah \& Ward, 2003; Singh et al., 2010). The identification of wastages (refers to non-value added activities) and eliminating them are the tough tasks for all the organizations (Karlsson \& Ahlstrom, 1996; Sanchez \& Perez, 2001; Hines et al., 2004; Moayad \& Shell, 2009).

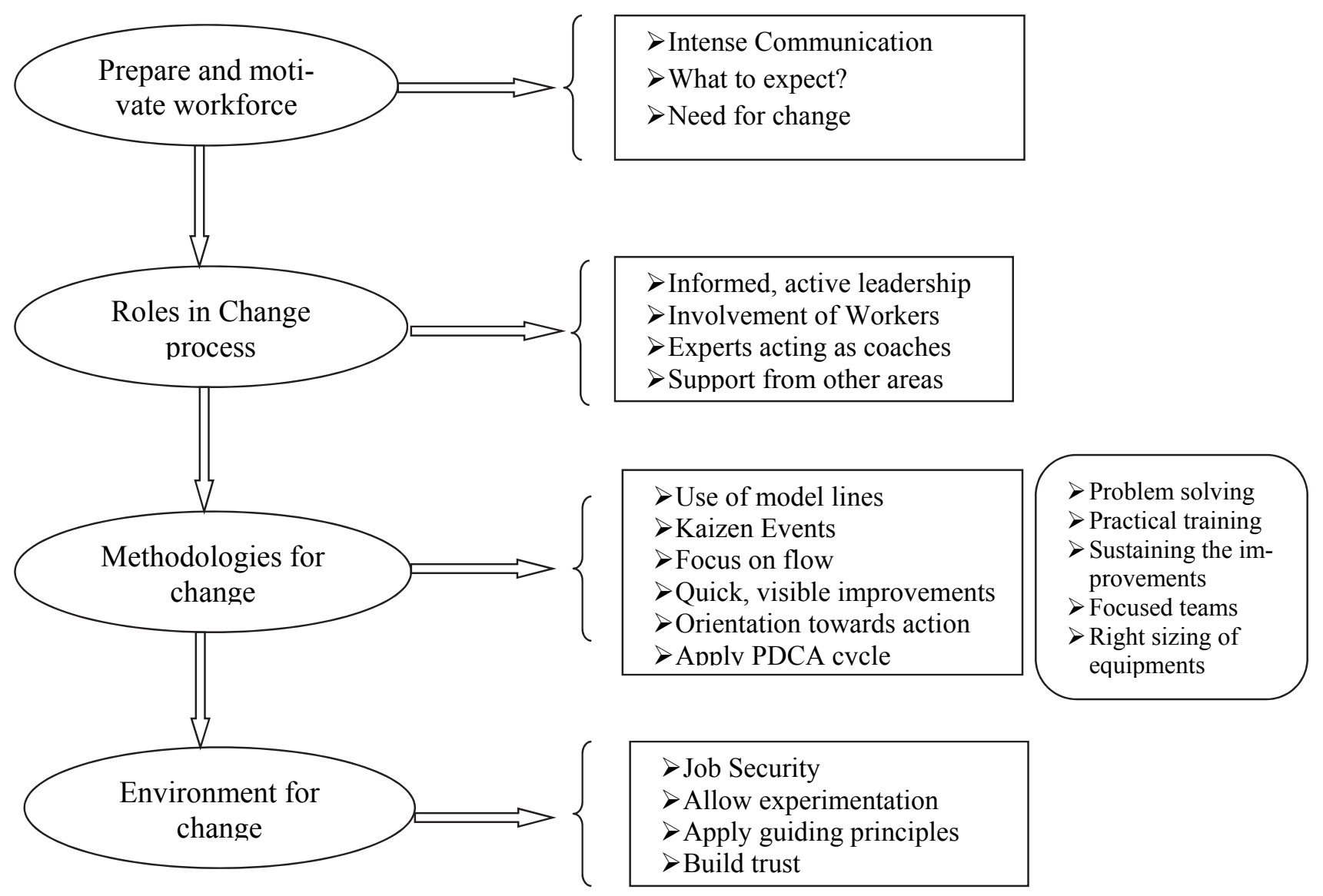

Fig. 1. Success factors for lean manufacturing (Duque \& Cadavid, 2007) 
In general, almost all the manufacturing industries (never adopted Lean Principles) are striving to their performance level because of the wastages incorporated with the process. In the manufacturing industry, the wastes are recognized by term TIMWOOD explained as:

- Transport Wastes: The transport waste means the unnecessary movement of resources within the organization, which never adds any value in the final product. Instead, value addition the unnecessary movement materials from one location to another add the extra cost in the product. Customer has no concern with the internal transportation of the material because he/she has the direct concern with the final product/service only. The literature reveals that few resources were exhausted during the transportation process results in increased production cost of the product/services.

- Inventory wastes: The inventory refers to holding raw material, work in progress or finished goods for the instant of time have the cost associated to store safely. In addition, the inventory wastes hides many of the other wastes like space consumption, extra manpower for logistics; and, always has the risk of being damaged during transport or becoming obsolete.

- Motion wastes: Unnecessary motion of resources (4'M) like the excessive travel b/w the workstations or the excessive manpower movements always has the domination on the production capacity of the plant. The unnecessary motion costs to the final process, which is being used for manufacturing the product instead of value addition.

- Waiting wastes: The waiting in the production process has the major influence on the production quantity and always results in inventory cost. The waiting means how much time that the product will wait for the processing to the succeeded workstation. This kind of waste disrupts resource flow results an additional cost which is almost $20 \%$ of the total cost incurred to manufacture the product.

- Overproduction wastes: This kind of waste is the most serious amongst all others because of working with oversize batches, long lead times, poor supplier relations and a host of other reasons like high levels of inventory, supply chain flexibility.

- Over processing Waste: This waste is directly associated with the process used for transformation of raw material into the final product/services. The main reasons for over processing are obsolete tools and techniques; over sizing of the equipment; and perform processes that are not depicted by the customer and so forth. The over processing on the materials always cause the cost and the increased production lead time.

- Defect: Almost all the organizations try to prevent the process where possible to produce the defect free production instead of identifying the cause and evaluation of their effects. This type of waste contributes a very small amount of wastages (Forza, 1996; Ahlstrom, 1998; Bozdogan et al., 2000; Anand \& Kodali, 2009).

At present the seven wastages listed and explained above are increased to 9 in nos. i.e.

- Talent Waste: This type of waste is directly associated with the work force performance of the organizations because the work force is considered as the greatest asset by far and can help the organization drive out the other kind of wastes. The organizations still tend to operate within a common command and close control environment. This is because of waste of talent i.e. using the workforce as the industry need not as per the capability of the workforce.

- Space Waste: The un-intended inventory and other resources always seeks to cover some floor space in an organization. Due to this fact, the organizations loose the opportunity to utilize the floor space to extend their business entities (Threja, 2011; Threja \& Kaushik, 2015; Kumar et al., 2015a; Kumar et al., 2016). 


\section{Research Study}

Before the twentieth century, the Indian manufacturing sector used to work on traditional approach i.e. push type approach i.e. products were produced and sent to the market. The customer perception was not conceived by the organizations, which further led to affect the sustainability in the global market. In other words, the manufacturer designed and developed the product as per their capabilities and sold to the market which sometime resulted in dissatisfaction of the customer. As proceeding further, the advanced tools were used for reduction in dissatisfaction cost to the customer (Pavnaskar, 2003). Still, they faced some challenges such as low cost production, emphasize on quality of the product, the delivery rate of the product to the customer etc.

Despite the fact, the organization always seeks to improve the performance inadequacies in man-machine management answers the following questions a) How to define the customer perception in terms quality of the entities?; b) Identification of ways to pursue the perfection to provide quality at the source itself; and c) Establishing the concept continuous improvement to emphasize on customer perception instead of market trend. Lean principles helps to answer the questions stated above up to some extent (Shah \& Ward, 2007; Rehman et al., 2010; Warnecke \& Husor, 2009). Perhaps, it is critical to evaluate and measure the status of lean principles on organizational performance.

\section{Methodology}

To identify and eliminate the wastes listed in introduction section; Lean Principles is the finest tool, which helps the organization convert the non-value added activities into the value added activities. Lean principles results in customer centric perspective of the organization that pulls the customer to buy more and more. The present study on Lean principles' impact on manufacturing context in India is accomplished with the help of ISM model. ISM approach is widely used approach for prioritizing the entities by using the structural set of different and directly related variables in the systematic model (Warfield, 1974; Sage, 1977). The model has the main aim to develop the direction of complex relationships among elements in a system with each other. The designed model in ISM has the logical structure with some complexity issues (Ansari et al., 2013; Kumar et al., 2013; Jayant \& Azhar, 2014). Therefore, the MICMAC analysis is used to develop the hierarchy based on the importance of each variable on others. Fig. 2 demonstrates the steps in ISM model used in the present work.

\section{Step 1: Identification of Lean principles impact on organizational Performance}

Extensive literature on Lean Principles has revealed the numerous tangible and intangible benefits of Lean Principles implementation in manufacturing sector. The twelve most common impacts on organizational performance were considered for the present study as listed below:

$\mathrm{I}_{1}$ : To provide the value to the customer

$\mathrm{I}_{2}$ : To emphasize the quality enhancement as continuous improvement process.

$\mathrm{I}_{3}$ : To minimize the resources losses from the unwanted transportation

$\mathrm{I}_{4}$ : To minimize the inventory wastages by controlling on all the business activities

$\mathrm{I}_{5}$ : To optimize the movement of men, material \& machine in the manufacturing process.

I6: To minimize the lead-time for production as well as purchasing

I7: To provide the better understanding on overproduction in an organizations

I $_{8}$ : Minimize the losses of resources caused by over-processing

$\mathrm{I}_{9}$ : Help in producing the defect free production

$\mathrm{I}_{10}$ : Helps in utilizing the full potential of its workforce to support the business activities

$\mathrm{I}_{11}$ : Helps in utilizing the space (Horizontally and Vertically)

$\mathrm{I}_{12}$ : Helps in providing the safest working conditions which has influence on business activities 
(Source: Katayama \& Bennett, 1996; Emiliani, 1998; Achanga et al., 2006; Puvanasvaran et al., 2008; Olivella et al., 2008; Anand \& Kodali, 2009a; Sharma \& Threja, 2011;Rajenthirakumar, 2011; Kumar et al., 2014,15,16).

Extensive literature review to identify the lean principles impact on organizational Performance

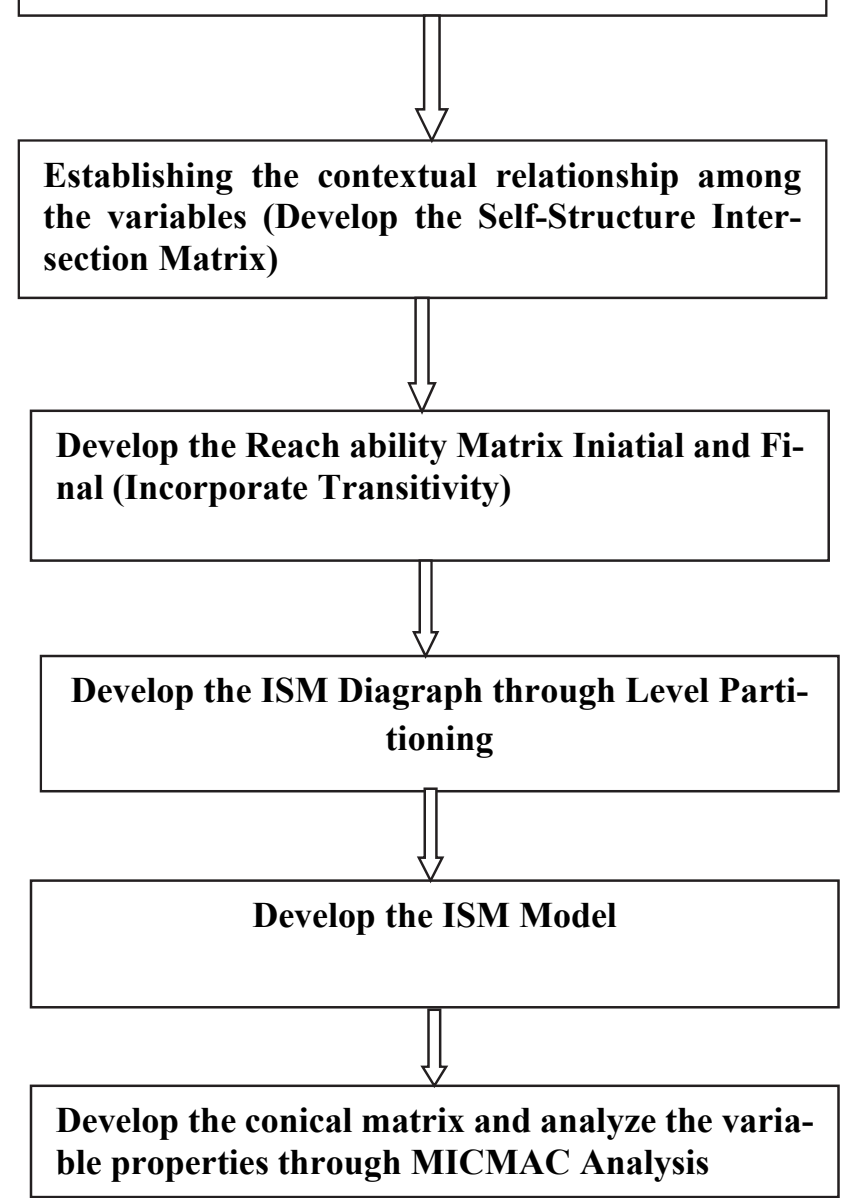

Fig. 2. Flow Chart for Present Study (Source: Luthra et al., 2011 (Modified))

\section{Step 2: Development of contextual relationship among variables}

The ISM approach is, in general, based on the contextual relationship among the different variables and is considered for study and their initial validation. In the present case, the contextual relationship among the impacts for implementing lean principles is done using Causal Approach based on the judgmental opinions of the experts working in the same areas. Table 2 below comprises the one to one contextual relationship for all the variables (impacts for implementing lean principles) using the standard rule. In Table 1 , the notations $V$ represents the variable $i$ leads to variable $j$ and variable $j$ does not lead the variable $i$. Similarly, notation $A$ represents the variable $j$ leads to variable $i$ and variable $i$ does not lead the variable $j$; notation $X$ represents the variable $i$ leads to variable $j$ and vice-versa; and the notation $O$ represents there is no relation appears in between variables $i$ and variable $j$. 
Table 1

Contextual relationship among lean principles impact in an organization

\begin{tabular}{c|ccccccccccc}
\hline \multicolumn{1}{c}{$\begin{array}{c}\text { LM Impact on } \\
\text { Performance }\end{array}$} & $\mathrm{I}_{12}$ & $\mathrm{I}_{11}$ & $\mathrm{I}_{10}$ & $\mathrm{I}_{9}$ & $\mathrm{I}_{8}$ & $\mathrm{I}_{7}$ & $\mathrm{I}_{6}$ & $\mathrm{I}_{5}$ & $\mathrm{I}_{4}$ & $\mathrm{I}_{3}$ & $\mathrm{I}_{2}$ \\
\hline $\mathrm{I}_{1}$ & $\mathrm{O}$ & $\mathrm{O}$ & $\mathrm{O}$ & $\mathrm{V}$ & $\mathrm{V}$ & $\mathrm{V}$ & $\mathrm{V}$ & $\mathrm{A}$ & $\mathrm{V}$ & $\mathrm{O}$ & $\mathrm{V}$ \\
$\mathrm{I}_{2}$ & $\mathrm{~A}$ & $\mathrm{~A}$ & $\mathrm{~A}$ & $\mathrm{~V}$ & $\mathrm{~V}$ & $\mathrm{~V}$ & $\mathrm{~V}$ & $\mathrm{~V}$ & $\mathrm{~V}$ & $\mathrm{~V}$ & \\
$\mathrm{I}_{3}$ & $\mathrm{~A}$ & $\mathrm{~V}$ & $\mathrm{~V}$ & $\mathrm{~A}$ & $\mathrm{~V}$ & $\mathrm{~V}$ & $\mathrm{~A}$ & $\mathrm{X}$ & $\mathrm{V}$ & & \\
$\mathrm{I}_{4}$ & $\mathrm{~A}$ & $\mathrm{~A}$ & $\mathrm{~A}$ & $\mathrm{X}$ & $\mathrm{V}$ & $\mathrm{V}$ & $\mathrm{A}$ & $\mathrm{V}$ & & & \\
$\mathrm{I}_{5}$ & $\mathrm{X}$ & $\mathrm{V}$ & $\mathrm{V}$ & $\mathrm{V}$ & $\mathrm{V}$ & $\mathrm{V}$ & $\mathrm{V}$ & & & & \\
$\mathrm{I}_{6}$ & $\mathrm{~A}$ & $\mathrm{~V}$ & $\mathrm{O}$ & $\mathrm{O}$ & $\mathrm{V}$ & $\mathrm{O}$ & & & & & \\
$\mathrm{I}_{7}$ & $\mathrm{~A}$ & $\mathrm{~A}$ & $\mathrm{~A}$ & $\mathrm{O}$ & $\mathrm{O}$ & & & & & \\
$\mathrm{I}_{8}$ & $\mathrm{~A}$ & $\mathrm{~A}$ & $\mathrm{~A}$ & $\mathrm{~A}$ & & & & & & \\
$\mathrm{I}_{9}$ & $\mathrm{~A}$ & $\mathrm{O}$ & $\mathrm{O}$ & & & & & & & & \\
$\mathrm{I}_{10}$ & $\mathrm{~A}$ & $\mathrm{X}$ & & & & & & & & & \\
$\mathrm{I}_{11}$ & $\mathrm{~A}$ & & & & & & & & & & \\
\hline
\end{tabular}

\section{Step 3: Development of SSIM}

After the development of contextual relationship among the variables, the binary matrix is developed by keeping the Table 1 as reference. Table 2 shows the Self Structured Interaction Matrix for the present study. The placing of 0's and 1's in the binary matrix is done by using the rule as follows:

- If the $(i, j)$ entry in the SSIM is $\mathrm{V}$, then $(i, j)$ entry in the SSIM becomes 1 and the $(j, i)$ entry becomes 0 .

- If the $(i, j)$ entry in the SSIM is A, then $(i, j)$ entry in the SSIM becomes 0 and the $(j, i)$ entry becomes 1 .

- If the $(i, j)$ entry in the SSIM is X, then both $(i, j)(j, i)$ entries in SSIM are become 1.

- If the $(i, j)$ entry in the SSIM is O, then both $(i, j)(j, i)$ entries in SSIM are become 0.

\section{For Example:}

- In Table 1 , the entry in $(1,4)$ is $\mathrm{V}$, so, in Table 2 , the entries in $(1,4)$ and $(4,1)$ becomes 1 and 0 respectively.

- In Table 2 , the entry in $(1,5)$ is $\mathrm{A}$, so, in Table 2 , the entries in $(1,5)$ and $(5,1)$ becomes 0 and 1 respectively.

- In Table 2 , the entry in $(4,9)$ is $X$, so, in Table 2 , both the entries $(4,9)$ and $(9,4)$ becomes 1 .

- In Table 2 , the entry in $(6,10)$ is $\mathrm{O}$, so, in Table 2 , both the entries in $(6,10)$ and $(10,6)$ becomes 0 .

Table 2

SSIM (Initial Reachability Matrix)

\begin{tabular}{c|cccccccccccc}
\hline LM Impact on Perfor- & $\mathrm{I}_{1}$ & $\mathrm{I}_{2}$ & $\mathrm{I}_{3}$ & $\mathrm{I}_{4}$ & $\mathrm{I}_{5}$ & $\mathrm{I}_{6}$ & $\mathrm{I}_{7}$ & $\mathrm{I}_{8}$ & $\mathrm{I}_{9}$ & $\mathrm{I}_{10}$ & $\mathrm{I}_{11}$ & \\
\hline $\mathrm{I}_{1}$ & 1 & 1 & 0 & 1 & 0 & 1 & 1 & 1 & 1 & 0 & 0 & 0 \\
$\mathrm{I}_{2}$ & 0 & 1 & 1 & 1 & 1 & 1 & 1 & 1 & 1 & 0 & 0 & 0 \\
$\mathrm{I}_{3}$ & 0 & 0 & 1 & 1 & 1 & 0 & 1 & 1 & 0 & 1 & 1 & 0 \\
$\mathrm{I}_{4}$ & 0 & 0 & 0 & 1 & 1 & 0 & 1 & 1 & 1 & 0 & 0 & 0 \\
$\mathrm{I}_{5}$ & 1 & 0 & 1 & 0 & 1 & 1 & 1 & 1 & 1 & 1 & 1 & 1 \\
$\mathrm{I}_{6}$ & 0 & 0 & 1 & 1 & 0 & 1 & 0 & 1 & 0 & 0 & 1 & 0 \\
$\mathrm{I}_{7}$ & 0 & 0 & 0 & 0 & 0 & 0 & 1 & 0 & 0 & 0 & 0 & 0 \\
$\mathrm{I}_{8}$ & 0 & 0 & 0 & 0 & 0 & 0 & 0 & 1 & 0 & 0 & 0 & 0 \\
$\mathrm{I}_{9}$ & 0 & 0 & 1 & 1 & 0 & 0 & 0 & 1 & 1 & 0 & 0 & 0 \\
$\mathrm{I}_{10}$ & 0 & 1 & 0 & 1 & 0 & 0 & 1 & 1 & 0 & 1 & 1 & 0 \\
$\mathrm{I}_{11}$ & 0 & 1 & 0 & 1 & 0 & 0 & 1 & 1 & 0 & 1 & 1 & 0 \\
$\mathrm{I}_{12}$ & 0 & 1 & 1 & 1 & 1 & 1 & 1 & 1 & 1 & 1 & 1 & 1 \\
\hline
\end{tabular}


Table 2 shows the SSIM and it is also known as the reachability matrix. The transitivity is incorporated in Initial reachability matrix, and developing the final reachability matrix. Transitivity helps to define the relationships between the three variables in such a manner that if variable A holds the relationship with variable $\mathrm{B}$; and the variable $\mathrm{B}$ holds relationship with $\mathrm{C}$, then there is a relation exist in between variable $\mathrm{A}$ and variable $\mathrm{C}$. Transitivity is marked as $1^{*}$ and shown in Table 3.

Table 3

Incorporating Transitivity (Final Reachability Matrix)

\begin{tabular}{c|cccccccccccc}
\hline $\begin{array}{c}\text { LM Impact on Perfor- } \\
\text { mance }\end{array}$ & $\mathrm{I}_{1}$ & $\mathrm{I}_{2}$ & $\mathrm{I}_{3}$ & $\mathrm{I}_{4}$ & $\mathrm{I}_{5}$ & $\mathrm{I}_{6}$ & $\mathrm{I}_{7}$ & $\mathrm{I}_{8}$ & $\mathrm{I}_{9}$ & $\mathrm{I}_{10}$ & $\mathrm{I}_{11}$ & $\mathrm{I}_{12}$ \\
\hline $\mathrm{I}_{1}$ & 1 & 1 & $1^{*}$ & 1 & $1^{*}$ & 1 & 1 & 1 & 1 & 0 & $1^{*}$ & 0 \\
$\mathrm{I}_{2}$ & $1^{*}$ & 1 & 1 & 1 & 1 & 1 & 1 & 1 & 1 & $1^{*}$ & $1^{*}$ & $1^{*}$ \\
$\mathrm{I}_{3}$ & $1^{*}$ & $1^{*}$ & 1 & 1 & 1 & $1^{*}$ & 1 & 1 & $1^{*}$ & 1 & 1 & $1^{*}$ \\
$\mathrm{I}_{4}$ & $1^{*}$ & 0 & $1^{*}$ & 1 & 1 & $1^{*}$ & 1 & 1 & 1 & $1^{*}$ & $1^{*}$ & $1^{*}$ \\
$\mathrm{I}_{5}$ & 1 & $1^{*}$ & 1 & $1^{*}$ & 1 & 1 & 1 & 1 & 1 & 1 & 1 & 1 \\
$\mathrm{I}_{6}$ & 0 & $1^{*}$ & 1 & 1 & $1^{*}$ & 1 & $1^{*}$ & 1 & $1^{*}$ & $1^{*}$ & 1 & 0 \\
$\mathrm{I}_{7}$ & 0 & 0 & 0 & 0 & 0 & 0 & 1 & 0 & 0 & 0 & 0 & 0 \\
$\mathrm{I}_{8}$ & 0 & 0 & 0 & 0 & 0 & 0 & 0 & 1 & 0 & 0 & 0 & 0 \\
$\mathrm{I}_{9}$ & 0 & 0 & 1 & 1 & $1^{*}$ & 0 & $1^{*}$ & 1 & 1 & $1^{*}$ & $1^{*}$ & 0 \\
$\mathrm{I}_{10}$ & 0 & 1 & $1^{*}$ & 1 & $1^{*}$ & $1^{*}$ & 1 & 1 & $1^{*}$ & 1 & 1 & 0 \\
$\mathrm{I}_{11}$ & 0 & 1 & $1^{*}$ & 1 & $1^{*}$ & $1^{*}$ & 1 & 1 & $1^{*}$ & 1 & 1 & 0 \\
$\mathrm{I}_{12}$ & $1^{*}$ & 1 & 1 & 1 & 1 & 1 & 1 & 1 & 1 & 1 & 1 & 1 \\
\hline
\end{tabular}

\section{Step 4: Development of the diagraph}

The diagraph for the present study is developed with the help of level partitioning i.e. developing the hierarchy of the variables according to their percentage of contribution in success/failure of the construct. This is done through identifying the reachability and antecedent set for each variable and their intersection points. This process is continued until all the variables are assigned the levels and shown with the help of diagraph in Fig. 2. Tables (4-8) in the present study represent the levels for all the variables (Impacts of Lean Manufacturing).

Table 4

First Level Partition

\begin{tabular}{c|llll}
\hline $\begin{array}{c}\text { LM Impact on Per- } \\
\text { formance }\end{array}$ & \multicolumn{1}{c}{ Reachability Set (RS) } & \multicolumn{1}{c}{ Antecedent Set (AS) } & Intersection & Level \\
\hline $\mathrm{I}_{1}$ & $1,2,3,4,5,6,7,8,9,11$ & $1,2,3,4,5,12$ & \\
$\mathrm{I}_{2}$ & $1,2,3,4,5,6,7,8,9,10,11,12$ & $1,2,3,5,6,10,11,12$ & \\
$\mathrm{I}_{3}$ & $1,2,3,4,5,6,7,8,9,10,11,12$ & $1,2,3,4,5,6,9,10,11,12$ & \\
$\mathrm{I}_{4}$ & $1,3,4,5,6,7,8,9,10,11,12$ & $1,2,3,4,5,6,9,10,11,12$ & \\
$\mathrm{I}_{5}$ & $1,2,3,4,5,6,7,8,9,10,11,12$ & $1,2,3,4,5,6,9,10,11,12$ & \\
$\mathrm{I}_{6}$ & $2,3,4,5,6,7,8,9,10,11$ & $1,2,3,4,5,6,10,11,12$ & \\
$\mathrm{I}_{7}$ & 7 & $1,2,3,4,5,6,7,9,10,11,12$ & 7 & \\
$\mathrm{I}_{8}$ & 8 & $1,2,3,4,5,6,8,9,10,11,12$ & 8 & $1^{\text {st }}$ \\
$\mathrm{I}_{9}$ & $3,4,5,7,8,9,10,11$ & $1,2,3,4,5,6,9,10,11,12$ & \\
$\mathrm{I}_{10}$ & $2,3,4,5,6,7,8,9,10,11$ & $2,3,4,5,6,9,10,11,12$ & \\
$\mathrm{I}_{11}$ & $2,3,4,5,6,7,8,9,10,11$ & $1,2,3,4,5,6,9,10,11,12$ & \\
$\mathrm{I}_{12}$ & $1,2,3,4,5,6,7,8,9,10,11,12$ & $2,3,4,5,12$ & \\
\end{tabular}


Table 5

Second Level Partition

\begin{tabular}{c|llll}
\hline $\begin{array}{c}\text { LM Impact on Perfor- } \\
\text { mance }\end{array}$ & \multicolumn{1}{|c}{ Reachability Set (RS) } & Antecedent Set (AS) & \multicolumn{1}{c}{ Intersection } & Level \\
\hline $\mathrm{I}_{1}$ & $1,2,3,4,5,6,9,11$ & $1,2,3,4,5,12$ & & \\
$\mathrm{I}_{2}$ & $1,2,3,4,5,6,9,10,11,12$ & $1,2,3,5,6,10,11,12$ & & \\
$\mathrm{I}_{3}$ & $1,2,3,4,5,6,9,10,11,12$ & $1,2,3,4,5,6,9,10,11,12$ & $1,2,3,4,5,6,9,10,11,12$ & $2^{\text {nd }}$ \\
$\mathrm{I}_{4}$ & $1,3,4,5,6,9,10,11,12$ & $1,2,3,4,5,6,9,10,11,12$ & $1,3,4,5,6,9,10,11,12$ & $2^{\text {nd }}$ \\
$\mathrm{I}_{5}$ & $1,2,3,4,5,6,9,10,11,12$ & $1,2,3,4,5,6,9,10,11,12$ & $1,2,3,4,5,6,9,10,11,12$ & $2^{\text {nd }}$ \\
$\mathrm{I}_{6}$ & $2,3,4,5,6,9,10,11$ & $1,2,3,4,5,6,10,11,12$ & $2,3,4,5,6,9,10,11$ & $2^{\text {nd }}$ \\
$\mathrm{I}_{9}$ & $3,4,5,9,10,11$ & $1,2,3,4,5,6,9,10,11,12$ & $3,4,5,9,10,11$ & $2^{\text {nd }}$ \\
$\mathrm{I}_{10}$ & $2,3,4,5,6,9,10,11$ & $2,3,4,5,6,9,10,11,12$ & $2,3,4,5,6,9,10,11$ & $2^{\text {nd }}$ \\
$\mathrm{I}_{11}$ & $2,3,4,5,6,9,10,11$ & $1,2,3,4,5,6,9,10,11,12$ & $2,3,4,5,6,9,10,11$ & \\
$\mathrm{I}_{12}$ & $1,2,3,4,5,6,9,10,11,12$ & $2,3,4,5,12$ & & \\
\hline
\end{tabular}

Table 6

Third Level Partition

\begin{tabular}{c|llll}
\hline LM Impact on Performance & Reachability Set (RS) & Antecedent Set (AS) & Intersection & Level \\
\hline $\mathrm{I}_{1}$ & 1,2 & $1,2,12$ & & \\
$\mathrm{I}_{2}$ & $1,2,6,12$ & $1,2,6,12$ & $1,2,6,12$ & $3^{\text {rd }}$ \\
$\mathrm{I}_{6}$ & 2,6 & $1,2,6,12$ & $2,3,4,5,6,9,10,11$ & $3^{\text {rd }}$ \\
$\mathrm{I}_{12}$ & $1,2,6,12$ & 2,12 & & \\
\hline
\end{tabular}

Table 7

Fourth Level Partition

\begin{tabular}{c|llcc}
\hline $\begin{array}{c}\text { LM Impact on Perfor- } \\
\text { mance }\end{array}$ & Reachability Set (RS) & Antecedent Set (AS) & Intersection & Level \\
\hline $\mathrm{I}_{1}$ & 1 & 1,12 & 1 & $4^{\text {th }}$ \\
\hline $\mathrm{I}_{12}$ & 1,12 & 12 & & \\
\hline
\end{tabular}

Table 8

Fifth Level Partition

\begin{tabular}{c|cccc}
\hline LM Impact on Performance & Reachability Set (RS) & Antecedent Set (AS) & Intersection & Level \\
\hline$I_{12}$ & 12 & 12 & 12 & $4^{\text {th }}$ \\
\hline
\end{tabular}

The level partition done earlier is summarized in Table 9, which clearly depicts that the lean principles' impacts on organizational performance are found on five levels in present study i.e. variables $\mathrm{I}_{7} \& \mathrm{I}_{8}$ are at the $1^{\text {st }}$ level; variables $\mathrm{I}_{3}, \mathrm{I}_{4}, \mathrm{I}_{5}, \mathrm{I}_{9}, \mathrm{I}_{10} \& \mathrm{I}_{11}$ at the $2^{\text {nd }}$ level; variables $\mathrm{I}_{2} \& \mathrm{I}_{6}$ at $3^{\text {rd }}$ level; variable $I_{1}$ at the 4th level and finally, the variable $I_{12}$ at the fifth level. On the basis of data shown in Table 9, the diagraph is developed as shown in Fig. 3.

Table 9

Level Partition

\begin{tabular}{clllc}
\hline LM Impact on & \multicolumn{1}{c}{ Reachability Set (RS) } & \multicolumn{1}{c}{ Antecedent Set (AS) } & \multicolumn{1}{c}{ Intersection } & Level \\
\hline $\mathbf{I}_{\mathbf{1 2}}$ & $1,2,3,4,5,6,7,8,9,10,11,12$ & $2,3,4,5,12$ & 12 & $5^{\text {th }}$ \\
\hline $\mathbf{I}_{\mathbf{1}}$ & $1,2,3,4,5,6,7,8,9,11$ & $1,2,3,4,5,12$ & 1 & $4^{\text {th }}$ \\
\hline $\mathbf{I}_{\mathbf{2}}$ & $1,2,3,4,5,6,7,8,9,10,11,12$ & $1,2,3,5,6,10,11,12$ & $1,2,12$ & $3^{\text {rd }}$ \\
$\mathbf{I}_{\mathbf{6}}$ & $2,3,4,5,6,7,8,9,10,11$ & $1,2,3,4,5,6,10,11,12$ & $2,6,9,10,11$ & $3^{\text {rd }}$ \\
$\mathbf{I}_{\mathbf{3}}$ & $1,2,3,4,5,6,7,8,9,10,11,12$ & $1,2,3,4,5,6,9,10,11,12$ & $1,2,3,4,5,6,9,10,11,12$ & $2^{\text {nd }}$ \\
\hline $\mathbf{I}_{\mathbf{4}}$ & $1,3,4,5,6,7,8,9,10,11,12$ & $1,2,3,4,5,6,9,10,11,12$ & $1,3,4,5,6,9,10,11,12$ & $2^{\text {nd }}$ \\
$\mathbf{I}_{\mathbf{5}}$ & $1,2,3,4,5,6,7,8,9,10,11,12$ & $1,2,3,4,5,6,9,10,11,12$ & $1,2,3,4,5,6,9,10,11,12$ & $2^{\text {nd }}$ \\
$\mathbf{I}_{\mathbf{9}}$ & $3,4,5,7,8,9,10,11$ & $1,2,3,4,5,6,9,10,11,12$ & $3,4,5,9,10,11$ & $2^{\text {nd }}$ \\
$\mathbf{I}_{\mathbf{1 0}}$ & $2,3,4,5,6,7,8,9,10,11$ & $2,3,4,5,6,9,10,11,12$ & $2,3,4,5,6,9,10,11$ & $2^{\text {nd }}$ \\
$\mathbf{I}_{\mathbf{1 1}}$ & $2,3,4,5,6,7,8,9,10,11$ & $1,2,3,4,5,6,9,10,11,12$ & $2,3,4,5,6,9,10,11$ & $2^{\text {nd }}$ \\
\hline $\mathbf{I}_{\mathbf{7}}$ & 7 & $1,2,3,4,5,6,7,9,10,11,12$ & 7 & $1^{\text {st }}$ \\
$\mathbf{I}_{\mathbf{8}}$ & 8 & $1,2,3,4,5,6,8,9,10,11,12$ & 8 & $1^{\text {st }}$ \\
\hline
\end{tabular}




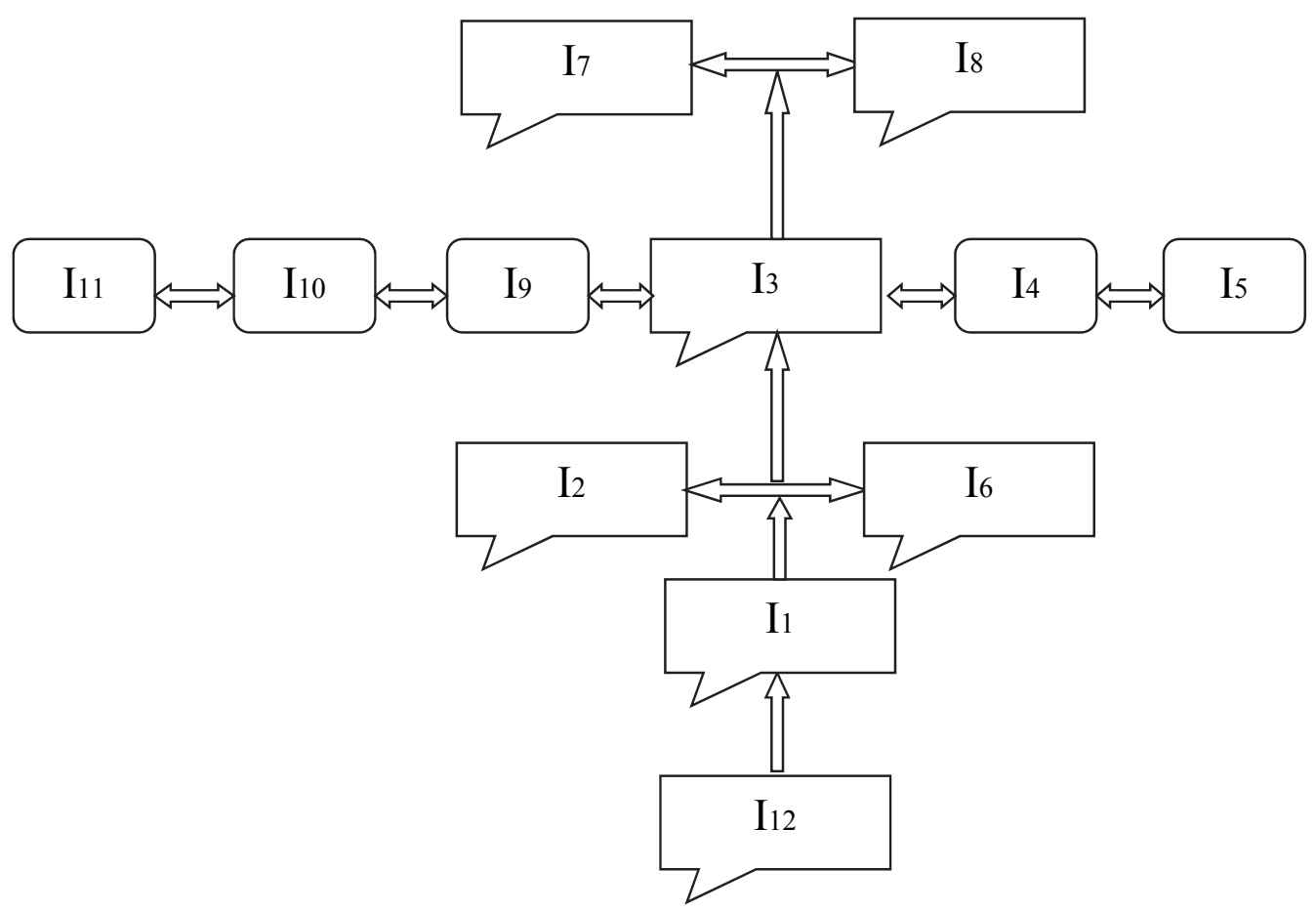

Fig. 3. Diagraph for the present study

\section{Step 5: Development of ISM model}

The diagraph shown in Fig. 2 is used and converted into an ISM model by replacing nodes of the elements with Lean Impacts as shown in Fig. 3. The ISM model for Lean Impacts on organizational performance reveals that the provision for safest working conditions in the manufacturing industry is the high driving power variable for implementation of LM. Further, the directional arrows in the model indicate that a particular variable is dictated by other one or helps in dictating to others. The positioning of the variables is performed based on their rankings with respect to their driving and dependence powers. The variable having high driving power may have the impact on the variables with less driving power. In the present case, the variable (safest working conditions in an organization) is found the high driving power that leads to the culture change i.e. helps in aligning the objectives of the individuals with the industry objectives. The model also reveals that the variables having higher driving power i.e. creation of value to customer also play an important role in the implementation of LM and they need to be specified before the process and more devotion is required because of their high driving and low dependency. The variables (Lean principle impacts) like Continuous improvement and lead-time minimization improves the process capability as well as the quality and cost of the product. Further, the variables (Lean principle impacts) control on overproduction and over processing are the dependent and having the lower driving value, which means the lean manufacturing approach is the better than the traditional one. In the traditional approach, the more emphasize is given to control on over-production and over-processing exhaust the other resources whereas lean principles systematically control on both the variables beginning from the safest working environment and customer value creation.

\section{Step 6 MICMAC analysis}

The MICMAC analysis is performed to analyze the driving or dependence power for the variables (Lean manufacturing impacts in the present study) as given in conical matrix (Table 11). 
Further, the variables are divided into four clusters based on their driving and dependence power as shown in Fig. 5.

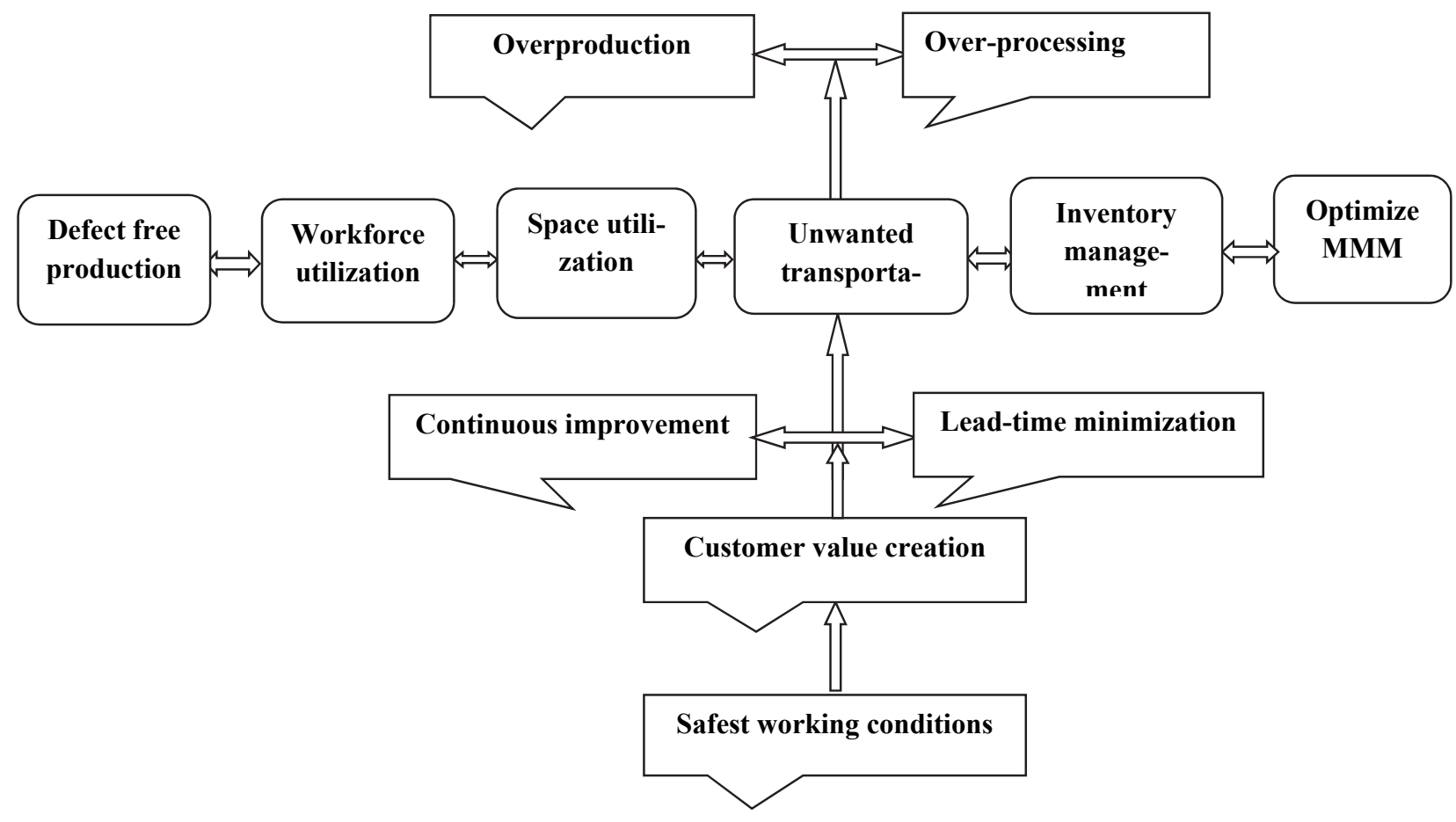

Fig. 4. ISM for the present study

Table 11

Conical Matrix

\begin{tabular}{lllllllllllll}
\hline Driving Power & 10 & 12 & 12 & 11 & 12 & 10 & 1 & 1 & 8 & 10 & 10 & 12 \\
\hline Dependence Power & 6 & 8 & 10 & 10 & 10 & 9 & 11 & 11 & 10 & 9 & 10 & 5 \\
\hline
\end{tabular}

Fig. 5 revealed the four regions i.e. a) Autonomous factors (Having weak power to drive as well as dependence on other variables); b) Dependent factors (Having weak drive power but strong dependence); c) Linkage factors (Having the strong drive power as well as strong dependence); and d) Driving factors (Having the strong drive power but weak dependence) (Luthra et al., 2011).

In present study, none of the variables of identity mix is independent. Further, the variable $I_{7} \& I_{8}$ are the dependent variables (have the little guidance power but extremely dependent to the system). These variables can seldom affect other variables but they are affected by others more. The variables such as $\mathrm{I}_{3}, \mathrm{I}_{4}, \mathrm{I}_{5}, \mathrm{I}_{9}, \mathrm{I}_{10} \& \mathrm{I}_{11}$ are the linking variables, which have a great guidance power and high degree of dependency. They not only affect the other variables, but also depend on other variables. The variable $\mathrm{I}_{1} \& \mathrm{I}_{12}$ are the driving variables having the high driving power and less dependency on others. 


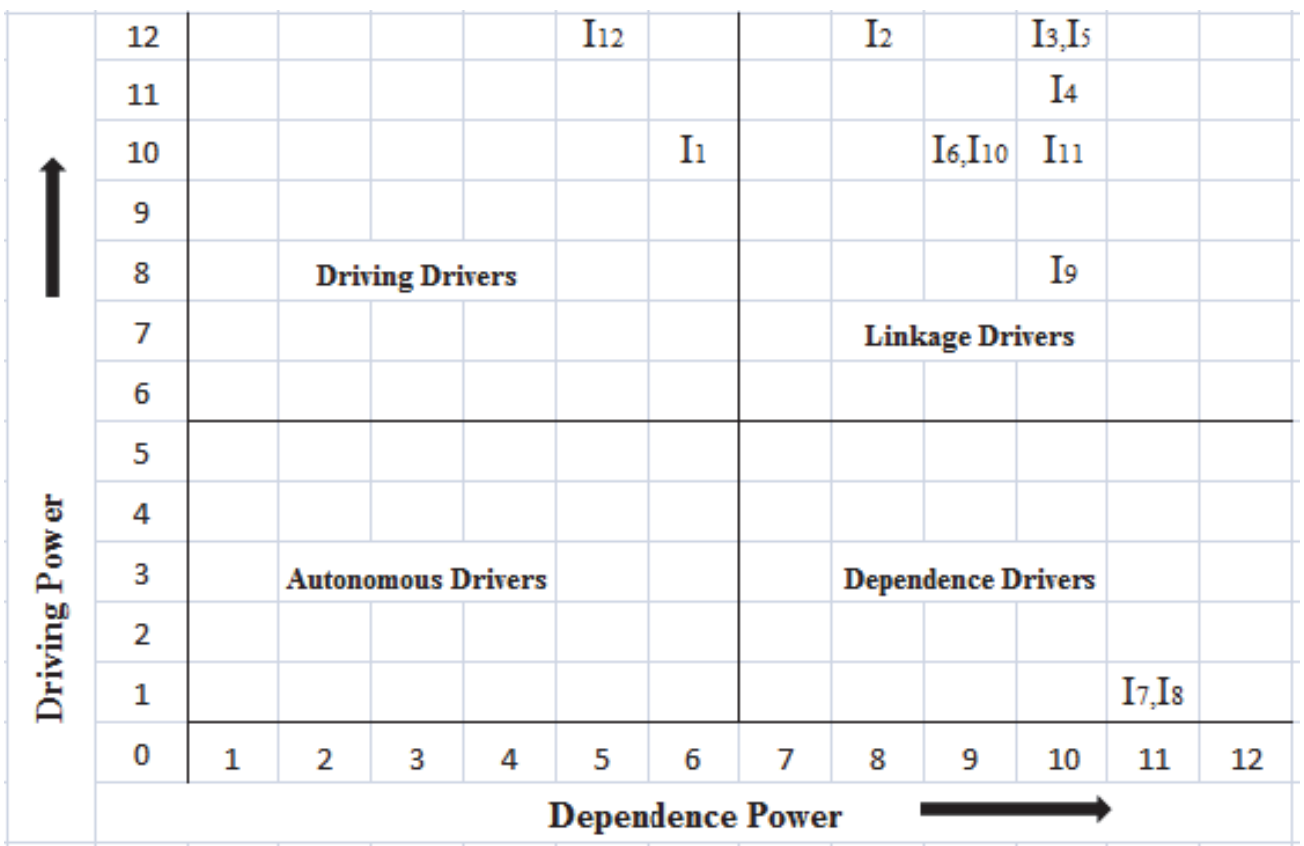

Fig. 5. The driving or dependence power for the variables

\section{Conclusion}

The objective of the paper was to develop the model to understand the impacts of lean principles on the organizational performance with the help of ISM approach and Micmac analysis. In the present study 12 lean impacts were identified through the extensive literature review and the model was formed based on the expert opinions. This ISM revealed the interrelationships between the construct lean principles and the impacts (variables). The literature revealed the researchers arguments on customers i.e. produce the product as desired by the customer. In other words, if there is a product in market for the customer, there is the value stream that requires the enough flexibility to meet the customer desires. The paper concludes that the safest working environment is the first and foremost activity followed by and value to the customer for all the entrepreneur's. Hence it becomes necessary to identify the various facts and facets about the safest working environment and the customer value i.e. customer desires on quality, quantity, and cost aspects.

The present work illustrates the various impacts of implementing lean manufacturing in Indian context along with the priority of task (hierarchy) to be performed for the competitive advantage and sustainability in the global market. Despite the useful findings, the present work has the implications in understanding i.e. all the measured variables (Lean manufacturing impacts on organizational performance) are considered through the extensive literature review. So, there might be the possibility that some variables are not included in the research. In future, the multiple data collection methods i.e. SEM approach is applied because it has the improvement over binary ISM.

\section{Acknowledgement}

The authors would like to thank the anonymous referees for constructive comments on earlier version of this paper. 


\section{References}

Abdulmalek, F.A. \& Rajgopal, J. (2007). Analyzing the benefits of lean manufacturing and value stream mapping via simulation: A process sector case study. International Journal of Production Economics, 107(1), 223-236.

Achanga, P., Shehab, E., Roy, R., \& Nelder, G. (2006). Critical success factors for lean implementation within SMEs. Journal of Manufacturing Technology Management, 17(4), 460-471.

Ahlstrom, P. (1998). Sequences in the implementation of lean production. European Management Journal, 16(3), 327-334.

Anand, G., \& Kodali, R. (2008). Selection of lean manufacturing systems using the PROMETHEE. Journal of Modelling in Management, 3(1), 40-70.

Anand, G. \& Kodali, R. (2009). Development of a framework for lean manufacturing systems, International Journal of Services and Operations Management, 5(5), 687-716.

Anand, G., \& Kodali, R. (2009a). Selection of lean manufacturing systems using the analytic network process-a case study. Journal of Manufacturing Technology Management, 20(2), 258-289.

Ansari, M. F., Kharb, R. K., Luthra, S., Shimmi, S. L., \& Chatterji, S. (2013). Analysis of barriers to implement solar power installations in India using interpretive structural modelling technique. Renewable and Sustainable Energy Reviews, 27, 163-174.

Belokar, R. M., Kumar, V., \& Kharb, S. (2012). An application of value stream mapping in automotive industry: A case study. International Journal of Innovative Technology and Exploring Engineering, $1(2), 152-157$.

Bhasin, S. and Burcher, P. (2006). Lean viewed as a philosophy. Journal of Manufacturing Technology Management, 17(1), 56-72.

Bozdogan, K., Milauskas, R., Mize, J., Nightingale, D., Taneja, A. and Tonaszuck, D. (2000). Transition to a Lean Enterprise: A Guide for Leaders, Massachusetts Institute of Technology, Cambridge.

Buffa, S.E. and Sarin, R.K. (2011). Modern production/Operation Management. Wiley India (P.) Limited, India, 8th edition.

Duque, D.F.M. \& Cadavid, L.R. (2007). Lean manufacturing measurement: the relationship between lean activities and lean metrics. Estudios Gerenciales, 23(105), 69-83.

Emiliani, M.L. (1998). Lean Behaviors. Management Decision, 36(9), 615-631.

Evans, J.R. and Lindsay, W.M. (2004). The management and control on Qulaity. South-Western Publication, Thomson Asia Pte. Ltd. Singapore (First Reprint), 3-4.

Forza, C. (1996). Work Organization in Lean Production and Traditional Plants: What are the differences?. International Journal of Operations \& Production Management, 16(2), 42-62.

Gulyani, S. (2001). Effect of poor transportation on Lean Production and Industrial clustering: Evidence from the Indian Auto Industry, World Development, 29(7), 1157-1177.

Hines, P. (1998). Benchmarking Toyota's supply chain: Japan vs U.K. Long Range Planning, 31(6), 911-918.

Hines, P., Holwe, M., \& Rich, N. (2004). Learning to evolve: A review of contemporary lean thinking. International Journal of Operations \& Production Management,24(10), 994-1011.

Jayant, A. and Azhar, M. (2014). Analysis of the barriers for implementing green supply chain management (GSCM) Practices: An Interpretive Structural Modeling (ISM) Approach. Procedia Engineering of 12th Global Congress on Manufacturing and Management (GCMM 2014), 97, $2157-$ 2166.

Karlsson, C. \& Ahlstrom, P. (1996). Assessing changes towards Lean Production. International Journal of Operations \& Production Management, 16(2), 24-41.

Katayama, H. \& Bennett, D. (1996). Lean Production in a changing competitive world: A Japanese perspective. International Journal of Operations \& Production Management, 16(2), 8-23.

Kumar, S., Luthra, S., \& Haleem, A. (2013). Customer involvement in greening the supply chain: an interpretive structural modeling methodology. Journal of Industrial Engineering International, $9(1), 1-13$. 
Kumar, R., Kumar, V., \& Singh, S. (2014). Effect of Lean Principles on organizational efficiency. In Applied Mechanics and Materials (Vol. 592, pp. 2613-2618). Trans Tech Publications.

Kumar, R., Kumar, V. \& Singh, S. (2015). Establishing the relationship among principles of lean Manufacturing, Supply Chain Characteristics, Manufacturing Strategies and Performance theoretically in an Indian environment. Journal of Industrial Engineering, 2, 25-31.

Kumar, R., Kumar, V., Singh, S. \& Theraja, P. (2015a). Managing the utility of manufacturing process facilities through Lean Supply Chain. Journal of Advance Research in Production and Industrial Engineering, 2(1), 13-23.

Kumar, R., Kumar,V., \& Singh, S. (2016). Relationship establishment between lean manufacturing and supply chain characteristics to study the impact on organizational performance using SEM approach, International Journal of Value Chain Management, 7(4), 352-367.

Kumar, R., \& Kumar, V. (2015) Lean manufacturing in Indian context: a survey. Management Science Letters, 5, 321-330.

Liker, J.K. (2004). The Toyota Way: 14 Management Principles From the World's Greatest Manufacturer. McGraw-Hill, New York.

Luthra, S., Kumar, V., Kumar, S., \& Haleem, A. (2011). Barriers to implement green supply chain management in automobile industry using interpretive structural modeling technique: An Indian perspective. Journal of Industrial Engineering and Management, 4(2), 231-257.

Olivella, J., Cuatrecasas, L. \& Gavilan, N. (2008). Work organization practices for lean production. Journal of Manufacturing Technology Management, 19(7), 798-811.

Pavnaskar, S.J., Gershenson, J.K. \& Jambekar, A.B. (2003). Classification scheme for lean manufacturing tools. International Journal of Production Research, 41(13), 3075-3090.

Puvanasvaran, A. Megat, M. Tang, S., Muhamad, M. and Hamouda, A. (2008). A Review of Problem Solving Capabilities in Lean Process Management. American Journal of Applied Sciences, 5(5), 504-511.

Rahman, S., Laosirihongthong, T., \& Sohal, A. S. (2010). Impact of lean strategy on operational performance: a study of Thai manufacturing companies. Journal of Manufacturing Technology Management, 21(7), 839-852.

Rajenthirakumar, D., Mohanram, P.V., \& Harikarthik, S.G. (2011). Process Cycle Efficiency Improvement Through Lean: A Case Study, International Journal of Lean Thinking, 2(1), 46-58.

Sage, A. (1977). Interpretive structural modeling: methodology for large scale systems. McGraw-Hill, New York, pp 91-164.

Sahoo, A.K., Singh, N.K., Shankar, A. \& Tiwari, M.K. (2008). Lean philosophy: implementation in a forging company, International Journal of Advance Manufacturing Technology, 36, 451-462.

Sanchez, A.M. \& Perez, M. (2001). Lean indicators and manufacturing strategies. International Journal of Operations \& Production Management, 21(11), 1433-1451.

Shah, R., \& Ward, P. T. (2003). Lean manufacturing: context, practice bundles, and performance. Journal of Operations Management, 21(2), 129-149.

Shah, R. and Ward, P.T. (2007). Defining and developing measures of lean production. Journal of Operations Management, 25, 785- 805.

Sharma. A. and Thareja, P. (2011). Leaning Pizza. Journal of Production Research \& Management, 1 (1), 1-18.

Singh, B., Garg, S. K., Sharma, S. K., \& Grewal, C. (2010). Lean implementation and its benefits to production industry. International Journal of Lean Six Sigma, 1(2), 157-168.

Sohal, A. (1996). Developing a lean production organization: An Australian case study. International Journal or Operations \& Production Management, 16(2),91-102.

Thareja, P. (2011). Casting people in continuous quality improvement, OmniScience: A Multidisciplinary Journal, 1(2), 1-20.

Thareja, P. \& Sharma, A. (2013). Lean learning through VSM. Journal of Production Research \& Management, 3(3). 16-26.

Thareja, P., \& Kaushik, S. K. (2015). VSM in aid of automotive industry's lean operations: A case study. Journal of Advanced Research in Production and Industrial Engineering, 1(2), 13-24. 
Upadhye, N., Deshmukh, S. G., \& Garg, S. (2010). Lean manufacturing system for medium size manufacturing enterprises: an Indian case. International Journal of Management Science and Engineering Management, 5(5), 362-375.

Warfield, J. N. (1974). Developing subsystem matrices in structural modeling. IEEE Transactions on Systems, Man and Cybernetics, 1, 74-80.

Warnecke, H. J., \& Hüser, M. (1995). Lean production. International Journal of Production Economics, 41(1-3), 37-43.

Womack, J.P., Jones, D.T., \& Roos, D. (1990). The Machine that Changed the World. Harper Perennial, New York.

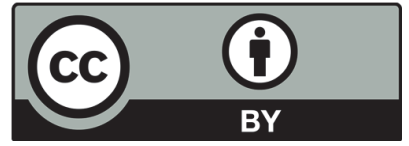

(C) 2017 by the authors; licensee Growing Science, Canada. This is an open access article distributed under the terms and conditions of the Creative Commons Attribution (CC-BY) license (http://creativecommons.org/licenses/by/4.0/). 